\title{
An Empirical Investigation Of The Minority Interest And Marketability Discounts In Valuation Of Closely Held Stock For Estate And Gift Tax Purposes
}

Ted D. Englebrecht, (Email: Tenglebr@cab.latech.edu), Louisiana Tech University Mary M. Anderson, University of Southern Mississippi

Otto Martinson, Old Dominion University

\begin{abstract}
The discounts for lack of marketability and minority interest are crucial in reducing the value of transferred interests of closely held companies for estate and gift tax purposes. Because the current highest marginal estate and gift tax rate is 49\%, there is a strong inducement for CPAs, Attorneys, Investment Bankers, Financial Planners, and others who value these transfers to accurately gauge the judicially allowed discounts for lack of marketability and minority interests in the valuation of closely held stock. This study examines the relationship between Tax Court determined values for lack of marketability and minority discounts to closely held stock from the compromise percentages. Compromise percentage is defined as the mean of the percentage presented by the adversarial parties, the taxpayer, and the IRS, in a judicial action. Additionally, this relationship is examined across industry classifications. The period investigated covers January 1, 1973 through December 31, 2002. Both regular and memorandum decisions by the Tax Court are analyzed over this thirtyyear span. Chi-square analysis is used to determine that the Tax Court determined values are not significantly different than the compromise percentages. Furthermore, this finding does not vary across industries. Regression and chi-squared results are augmented with descriptive statistics.
\end{abstract}

\section{INTRODUCTION}

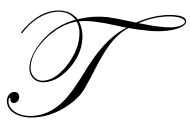

he closely held corporation, as its name implies, is a corporation whose shares are held either by a single shareholder or a relatively limited number of shareholders which has none of its stock traded on a public market (McClellan, 1996).

The general definition of closely held corporations, used in this study, is given by the U.S. Treasury in Revenue Ruling 59-60, 1959-1 CB 237:

Closely held corporations are those corporations the shares of which are owned by a relatively limited numbers of stockholders. Often, the entire stock issue is held by one family. The result of this situation is that little, if any, trading in the shares takes place. There is, therefore, no established market for the stock and such sales as occur at irregular intervals seldom reflect all of the elements of a representative transaction as defined by the term fair market value.

The need for valuing the shares of a closely held corporation arises whenever there is a disposition of part or all of the business entity. This valuation problem may occur because of sales, exchanges, charitable contributions, the need to determine an exchange rate in a proposed merger, the drafting of a buy-sell agreement, stock option plans, restricted stock plans, gifts or transfers at death. The consequences of valuing closely held stock for estate and gift tax purposes can be of immense importance to affected parties. For example, a taxpayer may have the majority of one's 
estate invested in a closely held family business. Without adequate estate planning, the federal estate taxes could force a sale of all or part of the ownership stock to derive funds to pay the tax.

Due to the lack of definitional statutes, Internal Revenue Service rulings and judicial decisions have set the standard for preparing valuations. With this scenario, it is not uncommon to find great disparity between the taxpayer's value and the value determined by the tax commissioner. Although the review process within the Service is understood to be similar to contract negotiations, oftentimes the parties fail to compromise. ${ }^{1}$ At this juncture, the taxpayer's recourse is the court system. Usually, these cases involve presentation of expert studies and reports by both the taxpayer and the IRS, followed by detailed trials. After thorough consideration of all aspects of the subject corporation's history, organization, product line, earnings, competition, and other relevant factors set forth in precedent and revenue rulings, the court will determine the stock value. Once a value is determined for the stock, the court will discount this figure for several reasons, including, where appropriate, the fact that the closely held stock is not readily marketable and that the decedent held a minority interest in the corporation.

Usually, little justification is offered for the values set by the courts. Both Hartwig (1954) and Bosland (1963) point out that the courts frequently appear to act as arbitrators who determine the "fair market value" to be approximately the arithmetic mean of the taxpayer's value and the commissioner's value, i.e., the "compromise theory."

Preliminary surveys appear to suggest that executors, donors, and the IRS may not actually be concerned with the fair market value of the shares of closely held stock in question. The purpose of the valuation is to measure the amounts of the estate tax or gift tax to be paid on the transfer of the shares. Given this purpose, the executors and donors would declare a value which they believe to be reasonable but which would minimize their tax liability. On the other hand, the IRS would value the shares in order to increase tax revenues. Additionally, with an unlimited marital deduction, the taxpayer may desire the higher valuation. ${ }^{2}$ Accordingly, valuation is a judgmental process, determined on a case-by-case approach. Because value and appropriate discounts are determined subjectively, with no objective standard to assess the accuracy of the value claimed by the taxpayer or the Service, it is appropriate to examine the discounts for lack of marketability and minority interests when valuing closely held stock for estate and gift tax purposes.

The primary objective of this study is to examine the relationship between the Tax Court determined values for lack of marketability and minority interest discounts applied in valuing closely held stock and those discounts put forth by the taxpayer and IRS. Answers are sought to the question of whether discount estimates based on authoritative criteria determine estate and gift tax liabilities or whether tax objectives based on compromise determine the valuation of closely held stock. In pursuit of this goal, a simple regression model based on compromise factors will be built and tested. A secondary objective of this study is to investigate if the judges on the Tax Court apply discounts for lack of marketability and for a minority interest differently across business classification (i.e. manufacturing, service, retail, and miscellaneous). Chi-square analysis will be used to test the proportionate decisions of the judges.

The remainder of this article is organized as follows: First, the origin, and applicability of legislative and administrative guidelines in valuing closely held corporations are presented. This is followed by a description of the nature and objectives of prior valuation studies. The third section provides an overview of the methodology to be used in this research inquiry; the fourth presents the results. Conclusions and implications of the study are discussed in the final section.

\section{VALUATION GUIDELINES}

Value is a concept that is elusive and subject to many meanings and interpretations. Justice Frank in Andrews v. Commissioner ${ }^{3}$ stated that attempts to define the meaning of value have all but driven men mad.

\footnotetext{
${ }^{1}$ Explain based on the IRS Manual.

${ }^{2}$ In this context, a higher valuation, not subject to transfer taxes as part of the marital deduction, establishes a greater basis for the ultimate sale of the securities. This greater basis results in a smaller taxable gain for income tax purposes.

${ }^{3} 135$ F.2d 314, 317 (CA-2, 1943).
} 
However, for estate tax and gift tax purposes, the term value implies the fair market value. This concept of value is represented by the Reg. Sec. 20.2031-1(b) definition:

The fair market value is the price at which the property would change hands between a willing buyer and a willing seller, neither being under any compulsion to buy or sell and both having reasonable knowledge of relevant facts.

Even though fair market value can be defined tightly, the concept is, nonetheless, extremely difficult to apply to closely held corporations whose shares are never or infrequently traded. Consequently, guidelines in the form of code sections, regulations, and administrative rulings have been established to assist executors, donors, tax advisors, bankers, and others in dealing with the problems inherent in valuing closely held securities.

\section{CODE SECTIONS ON VALUATION}

\section{Estate Tax} following:

The Internal Revenue Code defines gross estate in Code Section 2031. Embodied in Section 2031(b) is the

Valuation of unlisted stock and securities. In the case of stock and securities of a corporation the value of which, by reason of their not being listed on an exchange and by reason of the absence of sales thereof, cannot be determined with reference to bid and asked prices or with reference to sales prices, the value thereof shall be determined by taking into consideration, in addition to all other factors, the value of stock or securities of corporations engaged in the same or a similar line of business which are listed on an exchange.

\section{Gift Tax}

In the gift tax area, the applicable Code Sec. is 2512(a). This section on the valuation of gifts dictates that if the gift is made in property, the value thereof at the date of the gift shall be considered the amount of the gift. The precise definition of using fair market value and the related description of factors for valuing unlisted stock of closely held corporations for gift tax purposes is reserved for the regulations related to Code Sec. 2512.

\section{REGULATIONS ON VALUATION}

\section{Estate Tax}

The Regulations pertaining to Code Sec. 2031 define the gross estate and stipulate that the value of property is its retail fair market value, defined as that price that a willing buyer and a willing seller would agree upon. Reg. Sec. 20-2031-2 (a) states that the valuation of stocks and bonds is the fair market value per share on the applicable valuation date. Reg. Sec. 20-2031-3 discusses the Valuation of Interests in Business. That is, the fair market value of any interest of a decedent in a business, whether a partnership or a proprietorship, is a net amount which a willing purchaser, whether an individual or a corporation, would pay for the interest to a willing seller, neither being under any compulsion to buy or to sell and both having reasonable knowledge of relevant facts. The net value is determined on the basis of all relevant factors.

\section{Gift Tax}

The relevant gift tax regulations pertaining to Code Sec. 2512 are Regulation Sec. 25.2512-1; 25.2512-2(a); 25.2512-2(e); and 25.2512-2(f). Reg. Sec 25.2512-1 provides that when a gift is made in property, its value is determined at the date of the gift and this constitutes the amount of the gift. The value of the gift is defined as its retail fair market value that a willing buyer and a willing seller would agree upon. Reg. Sec. 25.2512-2(a) states in general that the value of gifts of stocks and bonds is their fair market value per share. 


\section{ADMINISTRATIVE RULINGS ON VALUATION}

\section{Revenue Ruling 59-60}

While several Revenue Rulings address the valuation of closely held corporate stock, Revenue Ruling 59-60 provides the foundation. This ruling outlines eight factors that the IRS considers basic and requires careful analysis in each valuation case of closely held stock. The factors delineated in Revenue Ruling 59-60 are as follows:

(a) The nature of the business and the history of the enterprise from its inception.

(b) The economic outlook in general and the condition and outlook of the specific industry in particular.

(c) The book value of the stock and the financial condition of the business.

(d) The earning capacity of the company.

(e) The dividend-paying capacity of the company.

(f) Whether or not the enterprise has goodwill or other intangible value.

(g) Sales of the stock and the size of the block of stock to be values.

(h) The market price of stock of corporations engaged in the same or similar line of business having their stocks actively traded in a free and open market, either on an exchange or over the counter.

While the determination of each factor is rather complex, the minority interest and marketability discounts are embedded in the last factor. As such, a brief explanation is warranted.

The price at which stock of comparable listed firms should be taken into consideration when valuing closely held shares. Exact comparability is generally unattainable, but a reasonable similarity based on same type of business, trend of sales and earnings, capital structure, and accounting methods, should be given due consideration.

Additionally, Rev. Rul. 59-60 provides that the relative importance of the above factors depends on the particular facts surrounding each case. The ruling further states that no useful purpose is served by taking a mathematical average of the factors in deriving the value of a closely held share. Such a process is not realistic and excludes other pertinent information.

\section{Revenue Ruling 81-253}

In response to the Estate of Bright v. Commissioner ${ }^{4}$ decision, the Service issued Revenue Ruling 81-253. The ruling held that no minority interest discount is allowed on the intra-family transfer of stock when the control of the corporation exists within the family unit. It defined "control" as either majority voting control or de facto control through family relationships. The ruling, specifically, noted that the Service would not follow the decision of the Fifth Circuit in Estate of Bright.

\section{Revenue Ruling 93-12}

Revenue Ruling 93-12 reversed the Service's earlier position in Revenue Ruling 81-253 on minority discounts. Pursuant to the facts of this ruling, a taxpayer owned 100 percent of a corporation's single class of outstanding stock. The taxpayer then transferred all of his shares by gift to his five children, each receiving $20 \%$ of stock. The IRS ruled that shares of other family members would not be aggregated in determining if the transferred shares should be valued as a controlling interest. This ruling permits greater emphasis to be placed on minority interests when valuing closely held stocks in the future.

Other pertinent Revenue Rulings serve to clarify specific situations that may arise during valuation (e.g., restrictive agreements, recapitalizations). Revenue Ruling 65-192 reiterated that the factors cited in Rev. Rul. 59-60 were the proper guidelines for valuing closely held stock for estate and gift tax purposes.

\footnotetext{
${ }^{4} 658$ F.2d $999\left(5^{\text {th }}\right.$ Cir., 1981$)$.
} 


\section{JUDICIAL}

The practice of "discounting" the value of a decedent's closely held stock for estate tax purposes is based on the realization that a minority interest in a closely held corporation is not as valuable as a majority held interest. Minority interests are subject to certain disadvantages: they cannot elect officers, declare dividends, or set corporate policy. Since these interests lack the control power of majority shares, courts and the Service allow them to discount their shares.

With closely held corporations, there is often not a ready market for trading the share of the corporation as contrasted to stocks of publicly held corporations. For this reason, courts will discount the fair market value of the closely held corporation to account for the lack of marketability.

In Estate of Andrews v. Commissioner ${ }^{5}$, the judiciary has defined both lack of marketability and minority discounts as follows:

The minority shareholder discount is designed to reflect the decreased value of shares that do not convey control of a closely held corporation. The lack of marketability discount is designed to reflect the fact that there is no ready market for shares in a closely held corporation.

\section{LITERATURE SURVEY}

Even though many articles have been published on the topic of valuing closely held corporations, only a few authors have systematically investigated the area. Accordingly, the work of these authors has been chosen.

Johnson, Shapiro, and O’Meara (1951) undertook a study to test for equity between owners of closely held stock and publicly owned stock for federal tax purposes. They felt that the disparity in treatment between listed and unlisted stocks for federal tax purposes was due predominantly to the subjective criteria employed in valuing unlisted stock. Consequently, disagreement and subsequent litigation between taxpayers and the IRS was frequent. The study set out to ascertain whether and to what extent quantitative relationships exist which account for and thus can be used to estimate or predict the price of listed stocks in terms of reported earnings and dividends or book value. If, in the case of listed stocks, a statistical pattern can be traced between price on the one hand and reported earnings, dividends or book value on the other, application of the pattern to closely held stock will yield comparable and thus equitable valuations. After examining earnings, dividends and book value of listed stocks, it was discovered that book value was the least responsive and dividends was the most dependable index to the price of listed stock on the New York Stock Exchange. Additionally, an absence of a stable relationship was apparent between earnings and price, between dividends and price, and between book value and price. Consequently, the authors felt that there is no price/earnings ratio or price/book value ratio or dividend yield which can be substituted as a result of thumb to be applied on a yearly basis. Further, the ratio of price to earnings, dividends, and book value showed a strong tendency to decrease as earnings increased.

Grunewald (1961) completed an exhaustive study of the usefulness of earnings, capitalization rates, and price-earning ratio multipliers in valuing stock of closely held corporations. He alleges that earning power should be the primary element in the valuation process and all other factors are of secondary importance. He also contends that other factors possess relevance only to the extent of their impact on past and future earnings. The record of past earnings, as reported in the income statement, furnishes the starting point for estimating future earnings. Additionally, he asserts that where the average of past earnings appear " fairly representative of the earning power of the organization, it may with a reasonable degree of confidence be projected into the future." Grunewald is in accord with other authors who feel that earnings patterns and trends should be analyzed.

Bosland (1963) surveyed executives in small family owned concerns in order to ascertain why small firms merged or sold out. His survey results indicated that potential estate and gift tax valuation problems and uncertainties

\footnotetext{
579 TC 938 (1982) at 953.
} 
were either very important ( $41 \%$ of the usable responses) or moderately important ( $22 \%$ of the usable responses) in their decision to sell out or merge. In addition to the questionnaire survey, Bosland attempted to shed more light on valuation problems by examining valuation cases appearing before the Tax Court from 1944 to 1960. Among Bosland's other conclusions about the Tax Court's attitude and conduct in valuation cases, he found that the variability in valuation criteria invites continued controversy as well as uncertainty. Additionally, there can be no question that the judges typically strive conscientiously to reach a fair verdict in valuation cases and there seems to be considerable basis for the contention that the judges of the Tax Court are inclined to reach compromise.

Huggins (1973) undertook in his study to determine if the Tax Court and Federal District Courts had kept pace with financial valuation models when valuing closely held corporations for estate and gift tax purposes. His investigation involved decisions of the above courts during the years 1951-1970. Fair market values for the cases utilized in the study were computed by utilizing theoretical financial valuation models. Huggins employed a Capitalization of Earnings Model, the Graham and Dodd model, and the Malkiel model. Among other findings, Huggins's research concluded that authoritative guidelines for valuing closely held stock are very vague. The empirical analysis showed no significant degree of association between financial valuation theory and the courts' methodology in valuing closely held stock for estate and gift tax purposes. The findings of this study appear to add support to the contention that the courts act as compromisers rather than objective valuers.

Englebrecht (1976) conducted the initial empirical investigation of Tax Court decisions on valuation. He applied a multiple regression analysis to eighty-five valuation cases over a twenty-five year period from 1950 to 1974 . The primary objective of this study was to determine whether the Tax Court uses legislative and administrative guidelines when valuing closely held stock. The secondary objective was to determine whether the Tax Court acts as an arbitrator between the IRS and the estate in determining value, i.e., whether the Tax Court simply chooses a middle ground between the values claimed by the litigants. Englebrecht's study provided evidence that the Tax Court employs guideline variables in valuing closely held stock. The taxpayer and the IRS also are using guideline variables that the Tax Court deems very important, such as book value, dividend paying capacity, etc. However, they are weighing theses factors in a manner which differs from that used by the Tax Court in order to minimize/maximize the tax liability, depending upon their perspective. The study introduced two models which would produce significant variables and high coefficients of correlation and determination.

Kramer (1982) developed mathematical models of Tax Court's decision results where blockage was a factor. One model explained 67 percent of the variance in Tax Court blockage valuations. Kramer's findings, like those of Englebrecht, reveal that much of the variance in Tax Court valuations can be explained by a relatively small number of variables.

Roberts (1988) investigated valuation decisions made by tax practitioners. A group of high and low experienced tax practitioners were given a representative valuation case. Two aspects of the practitioners' decision were examined: the present level of consensus among practitioners when valuing stock of closely held corporations for estate tax purposes and to what extent the differences in experience, firm association, and interactions affect the valuation decision. The results of this study provided evidence that neither experience nor firm-association were associated with significant differences in the fair market values determined by the practitioners. Roberts found that consensus among tax practitioners with respect to valuing closely held corporations is relatively low.

The review of prior valuation studies reveals a distinct lack of clarity, objectivity, and certainty in valuing closely held stock. It is readily apparent that the valuation of closely held stock is not a clear and unencumbered area of taxation.

Earles (1997) developed two multiple regression models for use in predicting the Tax Court determined value for marketability and minority interest discounts. Significant variables for marketability discounts are valuation date, size of transferred interest, return on equity, dividend paying capacity, leverage, and comparable companies. Significant variables for minority discounts are valuation date, size of transferred interest, and number of owners. In addition, this study gives evidence that both discounts have significantly decreased in recent years. 


\section{DATA AND RESEARCH METHODOLOGY}

\section{Data}

Taxpayers may initially bring cases before three legal forums. These courts are the Tax Court, U.S. District Court, and the U.S. Court of Federal Claims. The Tax Court is the only court of original jurisdiction in which the taxpayer does not have to pay the tax deficiency prior to filing suit. Because the other two courts hear predominately cases outside the of the taxation area, the Tax Court is considered the court of technical expertise. For these reasons, this study involves cases on valuation of closely held corporations for estate and gift tax purposes heard before the Tax Court. Additionally, a review of the estate and gift tax valuation cases revealed a paucity of cases in the District Courts and Court of Federal Claims in comparison to the Tax Court.

The data incorporated in this study represent a cross-section examination of Tax Court valuations of closely held stocks in federal estate and gift tax cases. The period investigated will cover January 1, 1973 through December 31, 2002. Both regular and memorandum decisions by the Tax Court will be analyzed by thirty-year time span, by ten years time spans, by amount of discounts, and by industry classification. A listing of all the cases included in this study is found in Appendix A.

\section{Methodology}

To examine the relationship between Tax Court determined values for lack of marketability and minority discounts applied to closely held stock and compromise percentages, a simple regression model and chi-square analysis will be employed.

Simple Regression Model. The simple regression model that will be used in this study is: $\mathbf{Y}_{\mathbf{e}}=\mathbf{B}_{\mathbf{0}}+\mathbf{B}_{\mathbf{1}} \mathbf{X}_{\mathbf{1}}$

Where:

$\mathbf{Y}_{\mathbf{e}}=$ percentage discounts for lack of marketability and minority interests applied.

$\mathbf{B}_{\mathbf{0}}=$ the $\mathrm{Y}$ intercept.

$\mathbf{B}_{\mathbf{1}}=$ beta coefficient.

$\mathbf{X}_{1}=$ arithmetic mean of the taxpayer and the IRS discounts for lack of marketability and minority interest.

\section{Null hypothesis (H01)}

There is no significant relationship between the Tax Court's minority and lack of marketability discount percentage allowed and the values produced by taking the arithmetic mean between the taxpayer's and the government's minority and lack of marketability discount value estimates.

The $\mathrm{F}$ ratio will be used to accept or reject the null hypothesis.

\section{Chi-Square Analysis}

A chi-square analysis will be performed for the lack of marketability and minority interest discounts across business classification (i.e. manufacturing, service, retail, and miscellaneous.

\section{Null Hypothesis (H02)}

There is no difference among industry classification of closely held stocks in proportion of discounts awarded above and below the compromise discount value. 


\section{STATISTICAL RESULTS}

\section{Correlation Analysis}

A coefficient of correlation was computed between the percentage discounts for lack of marketability and minority interests applied by the Tax Court and the arithmetic mean of the taxpayer and IRS discounts for lack of marketability and minority interests. The resulting correlation coefficient (R) was 0.7646 . This high coefficient shows a strong association between the Tax Court determined discounts and the arithmetic mean of the taxpayer and IRS discounts. Subsequently, this correlation coefficient was tested for significance by the F ratio. This ratio is computed as follows:

\section{$\mathrm{F}=\quad$ Variance explained by regression equation $\quad=\quad 199.86$ \\ Variance not explained by regression equation}

which is compared with table $\mathrm{F}$ with 1 numerator and 150 denominator degrees of freedom.

Since the table value of $\mathrm{F}$ at .01 is 6.81 and is far exceeded by the computed value of 199.86 , then the null hypothesis that no significant relationship exists between the Tax Court's discounts and the arithmetic mean of the taxpayer and IRS discounts is rejected. That is, there is a relationship between the Tax Court's discount for lack of marketability and minority interests and the arithmetic mean of the taxpayer and IRS discounts for lack of marketability and minority interests.

The coefficient of determination is a measure of the goodness of fit of a linear regression model and is expressed as follows:

\section{$\mathrm{r}^{2}=\quad$ Explained Variation/Total Variation}

Results indicate that over $58.46 \%$ of the variation in the Tax Court's determined discounts for lack of marketability and minority interest can be explained by the compromise variable.

\section{Chi-Square Analysis}

Chi-square computations were performed to test proportionate discounts for business classification (i.e., manufacturing, service, retail, and miscellaneous). Tables 1 and 2 provide the value for each cell in Table 3 . The value in each cell in Table 3 was found by squaring the observed value $\left(\mathrm{f}_{\mathrm{o}}\right)$ in each cell of Table 1 then dividing by the excepted value $\left(\mathrm{f}_{\mathrm{e}}\right)$ in each cell of Table 2 . The chi-square statistic was computed as follows:

\begin{tabular}{|c|c|c|}
\hline$\chi^{2}$ & $=$ & $\underline{\mathrm{f}}_{0} \frac{{ }^{2}-\mathrm{n}}{\mathrm{f}_{\mathrm{e}}}$ \\
\hline$\chi^{2}$ & $=$ & $100.9488-100$ \\
\hline$\chi^{2}$ & $=$ & .9488 \\
\hline
\end{tabular}

The table value for 3 degrees $(\mathrm{r}-1)(\mathrm{c}-1)$ of freedom is 11.345 at the .01 level of significance. Since the computed value $\left(\chi^{2}=.9488\right)$ is less than the table value, the null hypothesis of no difference among the discount valuations based on the type of underlying business is accepted. That is, compromise valuations established by the Tax Court appear to transcend strict categorical taxonomy by classification of business. However, it should be noted that, of the sixteen valuations that were at the compromise value and had to be removed from the analysis, thirteen of these compromise values were in the service classification. Of course, this adds greater credence to the compromise result in valuation. 
Table 1

BUSINESS DEMARCATION OF CLOSELY HELD STOCK VALUATIONS AS ABOVE AND BELOW THE COMPROMISE VALUE

\begin{tabular}{lccccc}
\hline \multicolumn{1}{c}{ Business Classification } & & & \\
\hline \multicolumn{1}{c}{ Valuations } & Miscellaneous & Service & Manufacturing & Retail & Totals \\
\hline Above the Compromise Value & 11.00 & 26.00 & 7.00 & 6.00 & 50.00 \\
Below the Compromise Value & 15.00 & 22.00 & 7.00 & 6.00 & 50.00 \\
Totals & 26.00 & 48.00 & 14.00 & 12.00 & 100.00 \\
\hline
\end{tabular}

* Seventeen valuations were at the compromise value (with thirteen of these in the service classification) and were removed from the analysis.

Table 2

EXPECTED DISTRIBUTION OF VALUATION ASSESSMENTS ABOVE AND BELOW THE COMPROMISE LEVEL

Business Classification

\begin{tabular}{lccccc}
\hline \multicolumn{1}{c}{ Valuations } & Miscellaneous & Service & Manufacturing & Retail & Totals \\
\hline Above the Compromise Value & 13.00 & 24.00 & 7.00 & 6.00 & 50.00 \\
Below the Compromise Value & 13.00 & 24.00 & 7.00 & 6.00 & 50.00 \\
\hline Totals & 26.00 & 48.00 & 14.00 & 12.00 & 100.00 \\
\hline
\end{tabular}

TABLE 3

COMPUTATIONS OF $\quad \Sigma \frac{\text { fo }^{2}}{}$

fe

Business Classification

\begin{tabular}{|c|c|c|c|c|c|}
\hline Valuations & Miscellaneous & Service & Manufacturing & Retail & Totals \\
\hline Above the Compromise Value & 9.3077 & 28.1667 & 7.00 & 6.00 & \\
\hline Below the Compromise Value & 17.3077 & 20.1667 & 7.00 & 6.00 & \\
\hline Totals & ------------- & ------------- & ------------- & ------------- & 100.9488 \\
\hline
\end{tabular}




\title{
OTHER MEASURES OF DISCOUNTS
}

\section{Means}

The most familiar measure of central tendency is the arithmetic mean. In Figures 1 and 2, it is quite evident, in each of the three decades represented, that the taxpayers mean discounts for lack of marketability and minority interest are always the largest. On the other hand, the IRS discounts are always the lowest, and the Tax Court mean discounts are always between the taxpayer and IRS discounts.

Table 4 provides a listing of the Taxpayer, IRS and Tax Court values which shows relationships to the mean, by industry. In 30 of the 117 valuation observations, the Tax Court's discount assessment was identical to the taxpayer's discount assessment. The taxpayer's discounts fell within a \pm 10 percent Tax Court's discount range 34 . At \pm 20 percent, the taxpayer's discounts were within the Tax Court's discounts on 46 decisions. However, in 58 decisions the taxpayer's discounts were within the minus $30 \%$ and over range.

Table 4

\begin{abstract}
Frequency Distribution of the Values Surrounding the Tax Court's Determined Percentage for Lack of Marketability and Minority Interest Discounts
\end{abstract}

Percentage Range

\section{$(\mathbf{T C} / \mathrm{TXP})^{\mathrm{A}}$}

130 and over
$120-129.99$
$110-119.99$
$100-109.99$
$90-99.99$
$80-89.99$
$70-79.99$
Below 70
Totals

1
0
3
34
4
11
19
43
$115^{\mathrm{D}}$

Frequency Count

$$
(\text { TC/IRS })^{\mathrm{B}} \quad(\mathrm{TC} / .5(\mathrm{TXP}+\text { IRS }))^{\mathrm{C}}
$$

44
7
5
27
2
1
0
3
$89^{\mathrm{E}}$

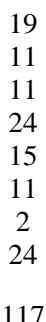

117

\footnotetext{
$A=$ Percentage of Tax Court's value for discounts compared to taxpayer's value for discounts. $\mathrm{B}=$ Percentage of Tax Court's value for discounts compared to IRS value for discounts.

$\mathrm{C}=$ Percentage of Tax Court's value for discounts compared to arbitrator's value for discounts. $\mathrm{D}=$ Taxpayer entered zero discount in 2 cases.

$\mathrm{E}=$ Internal Revenue Service entered zero discount in 28 cases
}

The Tax Court's discount assessment agreed with the discount determined by the IRS in 24 of the 117 valuation decisions. The IRS estimates were within a \pm 10 percent range of the Tax Court's discount in 32 decisions. At \pm 20 percent, the IRS estimates were within that range 38 times. The greatest frequency of IRS values fell above the plus 30 percent range. This happened in 38 decisions.

In 17 of the 117 valuation decisions, the Tax Court's discount assessments were identical to the arithmetic mean of the taxpayers and IRS discount percentages. The arithmetic mean between the taxpayers and IRS value was within $\mathrm{a} \pm 10$ percent Tax Court's value range 43 times. At \pm 20 percent, the number grew to 63 times. As a result, the largest frequency of occurrence involved the mean of the taxpayers and IRS discounts. Naturally, this result further augments the statistical results of compromise in assigning discounts for lack of marketability and minority interests. 


\section{Medians}

The median discount value is that value which divides the decade into two equal parts such that the number of discount values equal to or greater than the median is equal to the number of discount values equal to or less than the median. Of course, the median is not affected by extreme values like the mean. By reference to Figures 3 and 4 , the medians for Taxpayers, Service, and Tax Court discounts for lack of marketability and minority interests portray the same results as the mean disclosed. That is, the taxpayer claimed the highest discounts, the IRS the lowest discounts, and the Tax Court the discounts in the middle range.

\section{CONCLUSIONS AND IMPLICATIONS}

The foregoing study represents an attempt to determine if the Tax Court acts as an arbitrator when deriving discounts for minority interests and lack of marketability in estate and gift tax cases. From this study the authors draw a number of conclusions. Despite the individual nature of valuation cases, compromise discounts appear to be employed by the Tax Court. As such, the Tax Court, seemingly, employs guideline variables in arriving at the discount values. That is, the Court evaluates such factors as put rights, dividend payments, potential buyers, size of blocks, restrictive transfer precision's, discounting stockholder appraisal rights, contractual restrictions, financial conditions of the business, etc. On the other hand, taxpayers and the Service are also using the same valuation criteria that the Tax Court deems important. However, they are discounting these factors in a manner that differs from that used by the Tax Court. In other words, taxpayers submit high discounts to minimize tax liability, and the IRS submits low discounts to maximize the tax revenue.

The approach of this study on compromise is very different than the other studies on compromise. That is, the other studies looked at the macro final dollar figures for compromise, while, this study looked at the two important micro components of lack of marketability and minority interests. However, our results do indicate that a compromise value is arrived at on the average for these discounts. Nonetheless, because the Tax Court did agree with the taxpayer and the IRS on numerous occasions, it signifies that well prepared and defended discounts to valuation will be rewarded in court. Moreover, it appears that the Tax Court has settled on approximately $25 \%$ as the allowable discounts for lack of marketability and $15 \%$ for minority interests. Specifically, in Figures 1 and 2, the mean discounts for lack of marketability and minority interests in the decade of 1993-2002 was $25.35 \%$ and $14.82 \%$, respectively. Therefore, for taxpayers to keep the Service from litigating their positions on allowable discounts, the amount of the discounts should reflect these means. Additionally, with the recognition that the IRS review process is analogous to contract negotiations, it would be economically efficient for mandatory mediation as the next procedural step rather than judicial review.

\section{REFERENCES}

1. Bosland, Chelcie C. (1963). Estate Tax Valuation in the Sale or Merger of Small Firms, New York: Simmons-Boardman Publishing, p. 123.

2. Earles, Melanie J. (1997). Valuation of Closely-Held Companies for Estate, Gift, and Income Tax Purposes: Evidence of Minority and Lack of Marketability Discount. Doctoral Dissertation, Mississippi State University.

3. Englebrecht, Ted D. (1976). An Empirical Investigation into the Valuation of Closely Held Corporations by the Tax Court for Estate and Gift Tax Purposes. Doctoral Dissertation, The University of South Carolina, Columbia.

4. Grunewald, Adolph E. (1961). Stock Valuation in Federal Taxation, East Lansing: Bureau of Business and Economic Research, Michigan State University.

5. Hartwig, Joseph D. Valuation Problems Before the Internal Revenue Service and Tax Court. New York University Thirteenth Annual Institute on Federal Taxation, pp. 1143-1159.

6. Huggins, Kenneth M. (1973). The Valuation of Closely Held Corporation for Estate and Gift Tax Purposes. Doctoral Dissertation, Texas University.

7. Johnson, Lyle R., Shapiro, E., and O’Meara, J. O., Jr. (1951). Valuation of Closely Held Stock for Federal Tax Purposes: Approach to an Objective Method, University of Pennsylvania Law Review (100), 166-195. 
8. Kramer, Sandra S. Blockage Valuation of Large Blocks of Publicly Traded Stocks for Tax Purposes. The Accounting Review (57), 70-87.

9. Leacock, Stephen J. (2001). The Anatomy of Valuing Stock in Closely Held Corporations: Pursuing the Phantom of Objectivity into the New Millennium. Columbia Business Law Review (161).

10. McClellan, William A. (1996). Valuation of Closely Held Securities: Accounting Know-How is the Key. The Journal of Accountancy, March, p. 48.

11. Roberts, Michael L. (1988). Judgment and the Valuation of Closely Held Corporations for Estate Taxation. Doctoral Dissertation, Georgia State University.
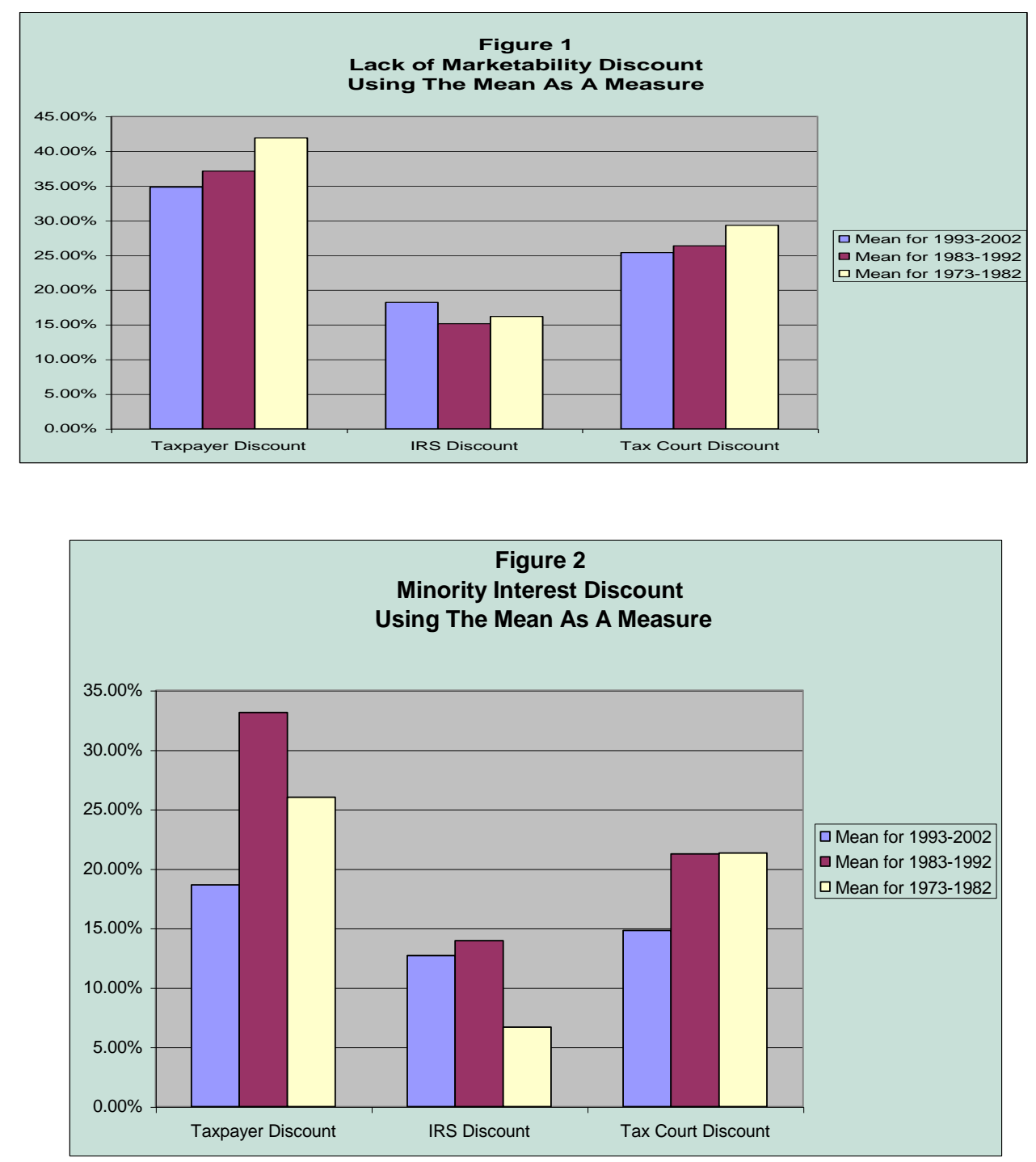

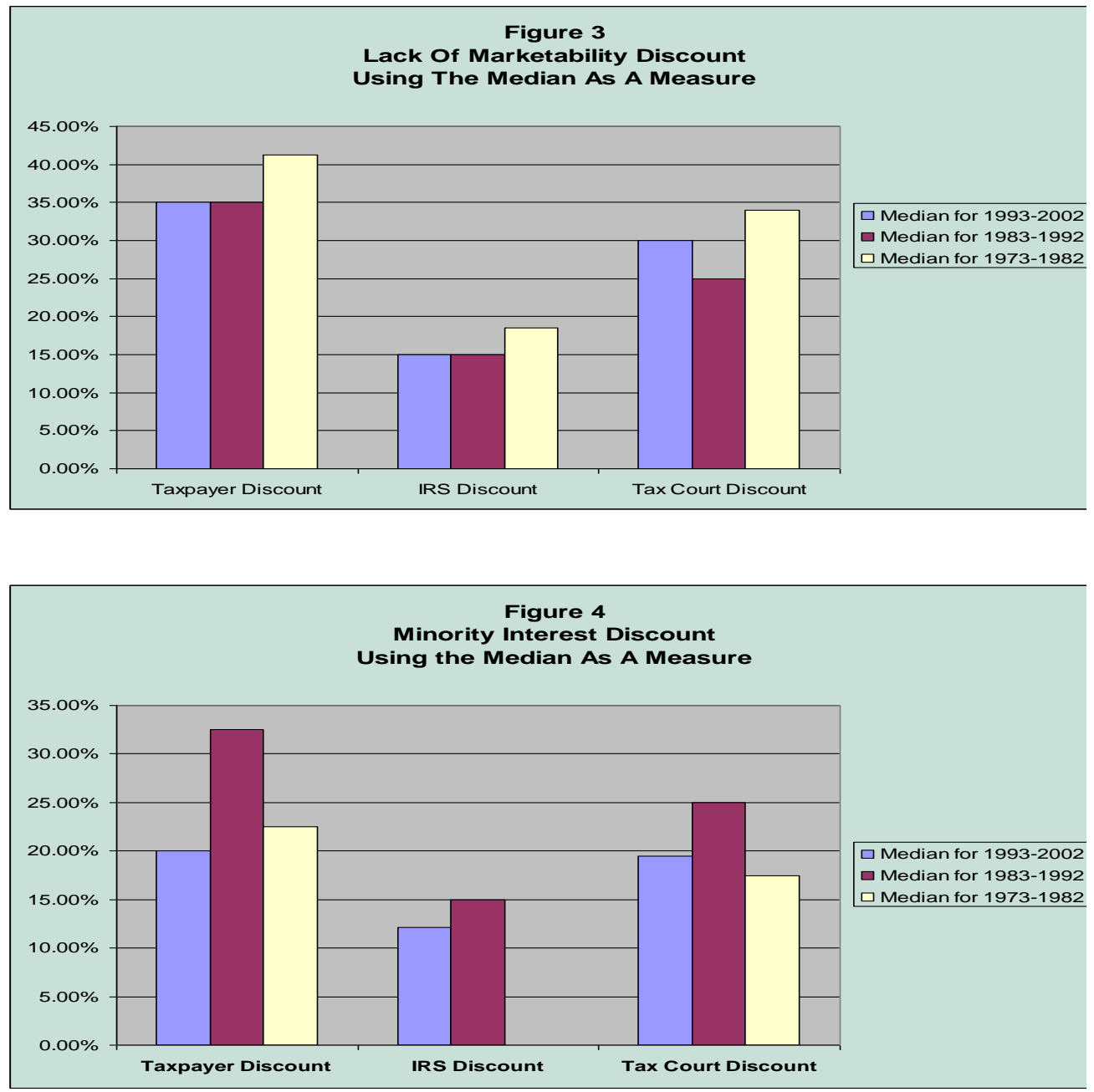
NOTES 